\title{
Advancement of Agricultural Technology in Farming of India
}

\author{
Avinash Sharma1, V.S. Devadas², Hemant Sharma', Bhagya, D. Kartha ${ }^{3}$, \\ Himanshu Pandey4, Gaytri Soni ${ }^{1}$, Supriya Sharma ${ }^{5}$, Nirupa Kumari ${ }^{5}$ \\ School of Agricultural Sciences, RNB Global University, Bikaner-334 601, Rajasthan, India.
}

Received: November 2021

Accepted: January 2022

\begin{abstract}
Background: Agricultural technology is an innovated, invented and discovered material that assists people and the country for improving production and productivity. Conventional agricultural technologies were practiced in the country in sustainable agriculture. A large number of inventions from several research and development projects were evolved and discovered that help in boosting transformation of sustainable agriculture into modern agriculture.

Methods: The agriculture technology is currently utilized in the dairy farming, poultry farming and organic farming. The working principles of agriculture technology were glanced from the dairy farming, poultry farming and organic farming and collected from the Andhra Pradesh, Karnataka, Maharashtra, Punjab and Gujarat.

Result: The control of fly, milking parlours, calf care, young stock housing, hygiene, milk testing technologies etc are currently utilized into the dairy farming in rural India. The robots carries out ding dirty work, flock protection using drones and use of sensors for monitoring and management are applied in the poultry animals. The Information and Communication Technology (ICT) contributes at production and management in dairy farming and poultry farming. It imposes crop development and management and sprays adequate organic chemicals in the crop field. The effective and less expensive technologies like neem based preparations, concentrated organic manure, organic formulations for seed treatment and plant protection, broad-spectrum botanical pesticides and many more have been developed that promote organic agriculture.
\end{abstract}

Key words: Agriculture technology, Dairy farming, Organic farming, Poultry farming.

\section{INTRODUCTION}

Agricultural technologies are innovated and invented in agricultural sciences since centuries provide many advantages to farming community and the country. The agricultural technologies are utilized in animal husbandry, crop farming, farm-linked activities, organic farming, protected cultivation, land development, climate and weather forecasting, agro-industries, agro-based industries and agricultural business. The sophisticated agricultural technologies are adopted in Japan, China, Israel, USA, Europe etc. for farming. In India Andhra Pradesh, Karnataka, Maharashtra, Punjab and Gujarat have adopted more agricultural technologies.

Indigenous technologies were utilized in agriculture till 50-60 years back, which supported a sustainable agriculture. Traditional agricultural technologies were thriving during sustainable agriculture. Several technologies were emerged in modern agriculture and boosted farming in modern agriculture. The agriculture technology progressed with education and farming practices and transformed into scientific farming. It generated skilled and unskilled employments in India. It improved agricultural business, food security and livelihood of people. It will continue improve the GDP and income of India.

The durable and farmer or user friendly agricultural technologies are utilized in farming for good production, management and agribusiness. Some farming sectors like dairy farming, poultry farming, protected cultivation, organic farming, smart farming etc. have enjoyed ghe benefits of innovations. Neila et al., (2016) explained that real time automatic devices are utilized in the poultry that monitors risks and animal health. The sensors can screen a farm environment, movement, or physiological parameter. The optical flow detects gait problems and feather pecking; infrared technologies are useful to evaluate birds thermo regulatory features and metabolic changes, that may be indicative of welfare, health and management problems. These technologies have potential to improve birds' welfare and to optimize flock management. Recently Zinich et al. (2021) explained that new production facilities will contribute to the growth of livestock production in subsequent years. The application of new production equipment in dairy farming improves the efficiency of the production. Suryatapa et al. (2020) stated that the organic technology protects the

*Corresponding author's E-mail: avinashcau@gmail.com

${ }^{1}$ School of Agricultural Sciences, RNB Global University, Bikaner-334 601, Rajasthan, India.

${ }^{2}$ School of Agriculture and Biosciences, Karunya Institute of Technology and Sciences, Coimbatore-641 114, Tamil Nadu, India.

${ }^{3}$ College of Agriculture, Kerala Agricultural University, Thrissur-680 656, Kerala, India.

${ }^{4}$ Department of Biotechnology, Dr. Y.S. Parmar University of Horticulture and Forestry, Solan-173 230, Himachal Pradesh, India.

${ }^{5}$ Department of Botany, Patna University, Patna-800 005, Bihar, India. 
environment and has a greater socio-economic impact on a nation. The organically grown foods are increasing day by day for nutritional and health benefits. Unmanned aerial vehicles (UAVs) or drones have been developed significantly over the past two decades, for a wide variety of applications such as surveillance, geographic studies, fire monitoring, security, military applications, search and rescue, agriculture, etc. In agriculture, for example, remote sensing by means of unmanned aerial vehicles has proven to be the most efficient way to monitor crops from images (Cuaran and Leon, 2021).

There have been tremendous developments in value addition and processing of horticulture crops also. Thermal methods are more popular and these traditional methods of fruit and vegetable preservation often affect the quality of final products in terms of color, taste, flavor and nutritional qualities. Several non-thermal methods of processing are developed in order to meet the consumer demand of which high pressure processing has proven to be extremely valuable for fruit and vegetable products (Archana and Lekshmi, 2020).

With this background, technological developments made in the following sectors of agriculture are discussed in this review paper:

i) Availability and applications of technology in dairy farming.

ii) Availability and applications of technology in poultry farming.

iii) Availability and applications of technology in organic farming.

\section{Novelty}

Constitution of modern production technology in the farming, Improvement of the system and documentation in the farming, Mitigation in the Health risk problems and animal loss, Progress in crop production and soil properties, Improvement in the skills, knowledge and adoption in the farmers, Transformation of sustainable agriculture into smart scientific agriculture.

\section{MATERIALS AND METHODS Materials}

The agriculture technology is utilized at diary faming, poultry farming and organic farming in India. The informations of agriculture technology were collected from the dairy farming, poultry farming and organic farming.

\section{Methods}

The agriculture technology is currently utilized in the respective farming. The working principles of agriculture technology were glanced from the dairy farming, poultry farming and organic farming and collected from the Andhra Pradesh, Karnataka, Maharashtra, Punjab and Gujarat.

\section{RESULTS AND DISCUSSION}

Availability and applications of technology in dairy farming

The dairy farming sector is an income generating sector that contributes to livelihood and national income of India.
The health tracking devices for cattle, robotic milking machines, cattle monitoring devices, product trace for customers through block chain, maintaining freshness of milk, automatic cattle traffic management, feed management, supply farm chain technology etc. are utilized in the present world. The cattle are kept in the barn design house that is constructed with asbestos and cement materials in India. Advanced facilities for drinking and watering for live stock, fly control, milking parlours, calf care, young stock housing, hygiene, milk tests etc. are presently employed in rural regions of Maharashtra, Karnataka, Punjab, Haryana, Madhya Pradesh and Gujarat in India. Water is provided in stainless steel material and fly control is handled with Carlmarks start set. The young calf is nurtured in Calf-tel Delux, Calf-tel Pen system and Calf-tel multimax. The camera is used for monitoring cattle populations. The Zorbisan Plus (GEA), Brize hyg iene powder are used for controlling bacteria and flies. The milk test is screened with milk test Duplex BL and TET (Fig 1). The awareness of diary technology is emerged in rural areas in India. It is assisted in cattle husbandry, management and income generation (Rik et al., 2017).

Over the years, the livestock keeping households have increased at a tremendous rate for the small and marginal, medium and semi-medium farm household categories as they reduce the risk arising from extreme climate conditions. So, it becomes imperative to adopt adaptation and mitigation strategies to reduce the impact of climate change on livestock given their importance in smallholder farmers' livelihood in India. The present policy of indiscriminate crossbreeding of local cattle with exotic cattle should be reviewed and reoriented for smallholder dairy farmer especially, in dry and rainfed regions where there is scarcity of fodder and water which are required heavily by crossbred cattle (Mahajan et al., 2015).

Availability and applications of technology in poultry farming

It is the productive farming sector in agriculture allied activities. It provides security and livelihood to rural people. The poultry producer was receiving a low income because of limited agriculture technology application. The product wastages are more because of improper management. Advanced technologies like robots are used in foreign countries for ding dirty works, drones for protecting the flock, sensors utilization for monitoring, block chain production safety and internet things for healthy production and income. The automated public fluid LED light level control, flickerfree lightning system, air quality monitor, water system designs, remote access livestock monitoring unit are presently utilized in India for scientific poultry farming (Fig 1). It will progress the income and security to rural and urban people (Gol, 2019).

Availability and applications of technology in organic farming

Organic farming is natural method of farming of crops without application of chemical fertilizers and synthetic pesticides and herbicides. 


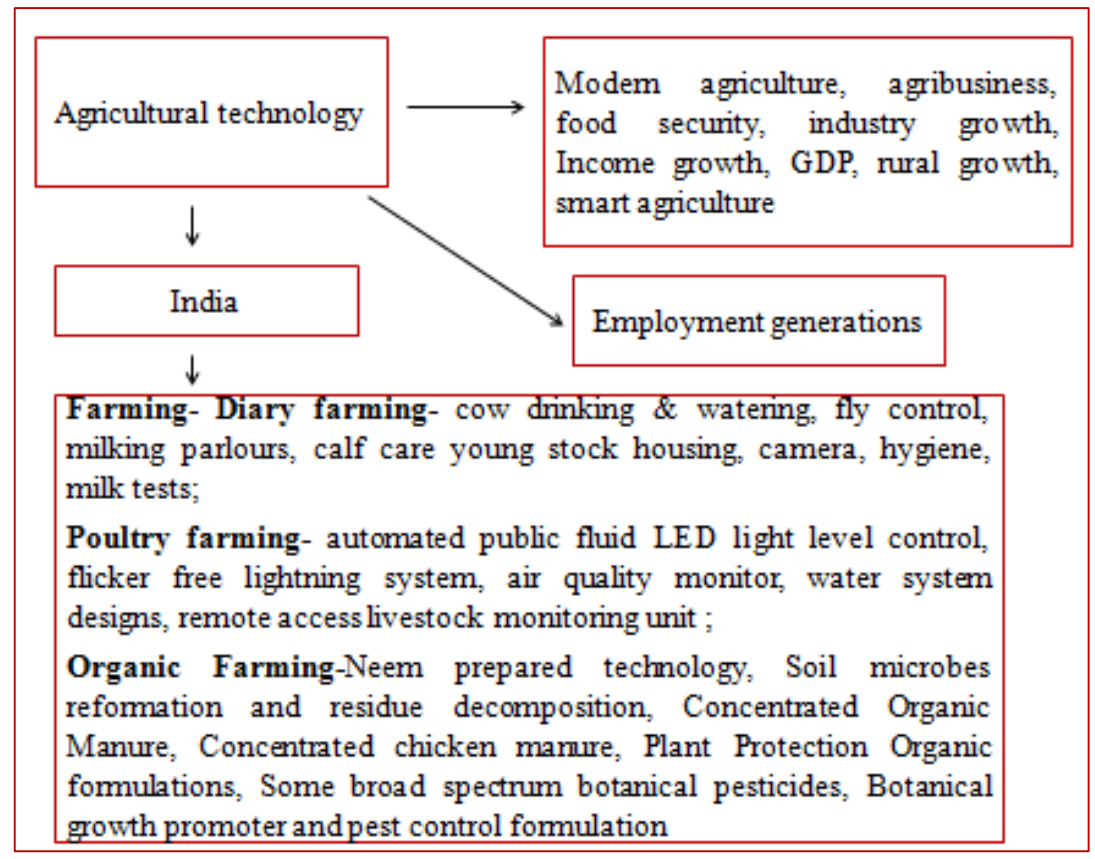

Fig 1: Agricultural technologies utilized in various farming sectors.

Himachal Pradesh, Madhya Pradesh and Maharashtra have the most organic agriculture area in the country. The country also has a leading position in organic production with consent increment in the organic producers throughout the globe. The country exports more than 135 products including basmati rice, cotton and oil corps (Yadav and Pandey, 2020). Use of liquid manures instead of bulky manures and biofertilizers are another development. Application in liquid form facilitates better release of nutrients, enhancement of soil microbial activity, improvement of soil aggregation, soil properties and soil health. Some of the famous liquid manures are jeevamruth, panchagavya, beejamruth, vermiwash, humic acid and sea weed extract. Based on these evidences this paper explores the effectiveness, importance and limitations of most commonly used organic liquid manures (Varshini and Jayanthi, 2020).

Several research and developmental programmes, projects were implemented in agricultural institutions for technology development to support and promote organic farming. Various indigenous and less expensive technologies were developed, tested and popularized in organic farming.

\section{i) Neem based preparations}

It is a less expensive organic technology employed in organic farming. Several neem- based technologies were developed by the Centre of Organic Farming, at Ghaziabad, Uttar Pradesh (RCOF 2019).

Specific combinations and procedures for preparation of various neem based products (neem fruit collection and de pulping, neem kernel aqueous extracts, neem cake extract, neem leaf extract, neem oil spray), soil microbes reformation and residue decomposition, Sanjivak, Jivamrut, Amrit Pani, concentrated organic manure, concentrated chicken manure, use of cow urine, vermiwash as growth promoter, Bijamrut, Dashparni extract, Panchgavya, enriched Panchgavya (Dashgavya), broad spectrum botanical pesticides (Neemastra, Brahmastra, Agneyastra) are prescribed for the use of farmers by RCOF, 2019. Apart from this, specific formulations and recommendations for control of a wide range of leaf eating and sucking pests (Formulation - 1 and Formulation - 2), nematode control in turmeric, control of prodenia and Heliothis larvae, natural pest control techniques, botanical growth promoters etc. are also recommended (RCOF, 2019).

\section{1) Neem prepared technology}

It is a less expensive organic technology that contributes to crop growth and farmer growth. Several neems derived technologies were prepared by the centre of organic farming i.e.

\section{a) Neem \\ Fruit collection and depulping}

- Collection of neem fruit from neem tree.

- Depulping of fruit from neem either by hand or mechanical depulper machine.

- Remove seed coat from neem seed.

- Store dried neem seeds in jute gunny bags or bamboo baskets.

- Dry the neem seed in shade or sunlight Select the place with good aeration. Do not dump the fruit or seed in a heap.

- Store neem seed in cool and dry place upto 6-12 months for oil extraction.

\section{b) Neem kernel aqueous extracts}

Collect $1 \mathrm{~kg}$ of clean and dried neem seed.

Make powder with mortar and pestle or any machine.

Add dried neem seed powder in 10 litres of clean water. 
- Add $10 \mathrm{ml}$ of neutral $\mathrm{pH}$ adjuvant (mixture of emulsifier, spreader etc.)

- Keep the solution overnight then next day filter the solution with muslin cloth 2-3 times then.

- Spray $1.25-5 \%$ NSKE during evening time.

- The effect remains for 7-10 days.

- It reduces the caterpillars, grubs, locusts and grasshopper populations.

\section{c) Neem cake extract}

- Take $100 \mathrm{gm}$ of Neem cake and 1 litre water.

- Put Neem cake in muslin cloth pouch form and pour in 1 litre water.

- Soaking will be done overnight then add neutral emulsifier $1 \mathrm{ml} / \mathrm{l}$.

- Apply for spray.

d) Neem leaf extract

- Take $1 \mathrm{~kg}$ green neem leaf and neem in 5 litres water and crush the leaf.

- Soak it overnight.

- Filter overnight leaf-water solution.

- Spray in the soil.

- It mitigates leaf eating caterpillar, grubs, locusts and grasshopper.

\section{e) Neem oil spray}

- Take 15-30 ml Neem oil and add in 1 litre water and stir it.

- Add $1 \mathrm{ml} /$ litre neutral emulsifier and mix thoroughly.

- Spray with knapsack sprayer.

2) Soil microbes reformation and residue decomposition

\section{i) Sanjivak}

- Mix 100-200 Kg cow dung + 100 litre cow urine + 500 gm jaggary in 300 litre water in 500 litre closed drum.

- Ferment for 10 days

- Dilute with 20 times water

- Sprinkle in one acre/soil spray/irrigation water.

- It sprays in 3 splits inthat first spray before sowing, second spray after 20 days of sowing and third spray 45 days after sowing.

- It uses in soil and microbes growth and residue decomposition.

\section{ii) Jivamrut}

- Mix $10 \mathrm{~kg}$ cow dung + 10 litre cow urine in 100 litre water.

- Mix well with wooden stick and add $2 \mathrm{~kg}$ jaggery $+2 \mathrm{~kg}$ gram or any pulse flour, mix well.

- Store solution for 5-7 days for fermentation and shake the solution 3 times in a day.

- It applies in soil through sprinkler and irrigation.

- It uses in soil and microbes growth and residue decomposition.

- It sprays in 3 splits inthat first spray before sowing, second spray after 20 days of sowing and third spray 45 days after sowing.

iii) Amrit pani

- Mix 10 kg cow dung + 500 gm honey and make creamy paste.
- Add 250 gm cow desi ghee and mix at high speed.

- Dilute with 200 litre water.

- Spray in 1 acre land through irrigation water and over the soil.

- It applies in rows of plant after 30 after sowing.

3) Concentrated organic manure

- Mix 10 parts rice bran +1 part fish meal +1 part oil cake + 1 part egg shell $+1-5 \%$ rock phosphate

- Add molasses and water separately (1:500).

- Keep ingredients in the container.

- Prepare heap on cement floor and cover with polythene sheet.

- Give first turning after $24 \mathrm{hrs}$.

- Turn mixture 2 times in a day.

- Maintain temperature of mixture below $40-45^{\circ} \mathrm{C}$.

- Compost will be ready within 4-5 days.

- It is used for compensating the nutrients of the soil.

\section{4) Concentrated chicken manure}

- Mix dry chicken manure + crushed oil cakes + some fresh ashes + rock phosphate in a ratio of 10:10:2:2.

- Grind the mixture to a fine powder.

- Excellent concentrated manure is ready.

- It is used for compensating the nutrients of the soil. for acidic soils, lime can also added to this mixture.

\section{5) Cow urine}

- Cow urine alone is also a good liquid fertilizer.

- Dilute 1 litre cow urine +100 lit of water in container. for 1 acre, prepares 200 litre solution.

- It can be used in any crop in all the seasons.

- It is applied as foliar spray.

6) Vermiwash as growth promoter

- Mix 1 litre vermiwash/0.5 litre vermiwash + 0.5 litre cow urine in 20 litre water.

- It applies as foliar spray.

- It uses 3-4 applications in leaf for good growth.

\section{7) Organic formulation for seed treatment}

\section{1) Bijamrut}

- Mix 5 kg cow dung + 5 litre cow urine +1 litre cow milk 1 litre $+250 \mathrm{gm}$ lime in drum with 100 litre water.

- Keep solution overnight.

- Sprinkle the solution over seeds for treatment.

- Dry the seeds and sow.

\section{8) Plant protection organic formulations}

\section{i) Dashparni extract}

- Mix 5 kg Neem Leaves, 2 kg Vitex negundo leaves, 2 kg Aristolochia Leaves, 2 kg Papaya (Carica Papaya), 2 kg Tinospora cordifolia leaves, $2 \mathrm{~kg}$ Annona squamosa (Custard apple) leaves, $2 \mathrm{~kg}$ Pongamia pinnata (Karanja) leaves, $2 \mathrm{~kg}$ Ticinus communis (Castor) leaves, $2 \mathrm{~kg}$ Nerium indicum, $2 \mathrm{~kg}$ Calotropis procera leaves, $2 \mathrm{~kg}$ Green chilly paste, $250 \mathrm{gm}$ Garlic paste, $3 \mathrm{~kg}$ Cow dung, 5 litre Cow Urine, 200 litre Water.

- Crush all the ingredients in the 500 litre drum. 
- Ferment for 1 month.

- Keep the drum in shade and cover with gunny bag.

- Shake 3 times in a day.

- Filter the solution

- Filter solutions stores in drum for 6 months

- It is used in insect-pests in 1 acre land.

\section{ii) Panchgavya}

- Mix 4 kg cow dung slurry, 1 kg fresh cow dung, 3 litre cow Urine, 2 litre, cow milk, 2 litre curd, $1 \mathrm{~kg}$ cow deshi ghee.

- Mix thoroughly and ferment for 7 days.

- Stir the mixture 2 time per day.

- Dilute 3 litre of Panchgavya solution in 100 lit water.

- Spray over soil and through irrigation water.

- For 1 acre, 20 litre Panchgavya solution requires for soil application and irrigation water.

- Soak seeds for 20 min before sowing.

- Panchgavya can also be used for seed treatment.

\section{iii) Enriched Panchgavya (Dashgavya)}

- Mix $1 \mathrm{~kg}$ fresh cow dung, 3 litre cow urine, 2 litre cow milk, 2 litre curd, $1 \mathrm{~kg}$ cow deshi ghee, 3 litre sugarcane juice 3 litre coconut water, banana 12 fruits paste.

- Mix thoroughly and ferment for 7 days.

- Stir the mixture 2 time per day.

- Dilute 3 litre of Panchgavya solution in 100 lit water.

- Spray over soil and through irrigation water.

- For 1 acre, 20 litre Panchgavya solution requires for soil application and irrigation water.

- Soak seeds for 20 min before sowing.

- Panchgavya can also be used for seed treatment.

9) Some broad spectrum botanical pesticides

i) Neemastra

- Crush $5 \mathrm{~kg}$ neem leaves in water.

- Add 5 lit cow urine and $2 \mathrm{~kg}$ cow dung.

- Ferment for 24 hrs.

- Filter the solutions and dilute 100 litres.

- For 1 acre, It applies for foliar spray.

- It is useful against sucking pests and mealy bugs.

ii) Brahmastra

- Crush $3 \mathrm{~kg}$ neem leaves +10 litre cow urine in one conatiner.

- Crush $2 \mathrm{~kg}$ custard apple leaf $+2 \mathrm{~kg}$ papaya leaf $+2 \mathrm{~kg}$ pomegranate leaves $+2 \mathrm{~kg}$ guava leaves in water in second container.

- Mix two container, boil 5 times at some interval till it becomes half.

- Keep for 24 hrs.

- Filter and extract the solutions.

- Stores in bottles for 6 months

- For 1 acre, dilute 2-2.5 litre solutions in 100 litre water.

- Useful against sucking pests, pod/fruit borers.

ii) Agneyastra

- Crush $1 \mathrm{~kg}$ Ipomea (besaram) leaves + $500 \mathrm{gm}$ hot chilli, 500 gm garlic $+5 \mathrm{~kg}$ neem leaves +10 litre cow urine.
- Boil 5 times till it becomes half.

- Filter and extract the solutions

- Store in glass or plastic bottles

- For 1 acre, 2-3 litre extracted solution/filtered solution for 100 litre water.

- Useful against leaf roller, stem/fruit/pod borer.

10) Formulation - 1 for wide range of leaf eating and sucking pests

- Mix $3 \mathrm{~kg}$ crushed neem leaves + $1 \mathrm{~kg}$ neem seed kernel powder with 10 lit cow urine in copper container.

- Ferment for 10 days.

- Filter and extract the solutions, boil the solutions upto half Prepare separately 500 gm garlic paste +250 gm chilli paste in 1 litre water, keep overnight.

- Next day, 2 solutions and filter the solutions.

- For 1 acre, Dilute to 200 lit with water and use as foliar spray over one acre.

11) Formulation - 2 for wide range of leaf eating and sucking pests

- Mix 5 kg neem seed kernel powder + 1 kg Karanja (Pongamai) seed powder $+5 \mathrm{~kg}$ chopped neem leaves $+5 \mathrm{~kg}$ chopped leaves of besharam (Ipomea)+ 10-12 litre cow urine in a 200 lit drum and fill with water.

- Ferment for 10 days.

- It uses as pesticide.

- For 1 acre, dilute in 200 litre water.

12) Nematode control in turmeric

- Grind 250 gm ginger + 250 gm Chilli +1.0 kg Nirgudi leaves (Vitex negundo) +500 gm garlic, 500 gm Aloe Vera $+1 \mathrm{~kg}$ neem seeds $+1 \mathrm{~kg}$ Cleodendron inerme, make paste mix with 150-lit water.

- Apply over soil.

- 1 acre, 120 days after planting.

\section{3) Control of prodenia and Heliothis larvae}

- Crush and Mix 4 kg Aloe Vera (Korfad) + $500 \mathrm{ml}$ neem oil $+500 \mathrm{ml}$ tobacco decoction in 20 lit of water.

- Boil till volume reaches to 5 litre.

- Filter the soultion.

- Dilute with 100 litre water and

- Use as foliar spray.

- Repeat spray after 10 days.

14) control of army worm, aphids, cotton semilooper, green leaf hopper, mites, powdery mildew, pulse beetle and rice weevil

- $1 \mathrm{~kg}$ Turmeric+ 4 liters of cows urine with 20 liters of water.

15) Control of American ball worms, aphids, pulse beetle white fly

- Make 500 gm garlic paste in $100 \mathrm{ml}$ kerosene + $100 \mathrm{gm}$ chilly paste in $50 \mathrm{ml}$ water $+100 \mathrm{gm}$ ginger paste.

- Add all the paste in 30 litre water with neutral emulsifier. - Spray in open field. 


\section{6) Control of aphids and beetles}

- Take 500 gm custard apple seed in 2 litres water and boil till $500 \mathrm{ml}$ solution reach.

- Mix in 15 litres water and spray over the crop.

- $2 \mathrm{~kg}$ custard apple leaves fresh juice in $500 \mathrm{ml}$ water $+500 \mathrm{gm}$ chilli water extract $+1 \mathrm{~kg}$ Neem seed extract in 2 litre water.

- Dilute in 60 litre water.

\section{7) Natural pest control techniques}

\section{1) Fungal disease control}

- Prepare 2-3 kg ash + 1 litre castor oil and sprays $100 \mathrm{~m}^{2}$ seed bed.

- Spray 2-3 times after 7-10 days interval.

- It protects from soil borne diseases.

- Prepare $2 \mathrm{~kg}$ of turmeric powder $+8 \mathrm{~kg}$ wood ash, dust over leaves for powdery mildew disease.

- Prepare 20 gm ginger powder in 1 litre water, sprays 3 times after 15 days and controls powdery mildew and other fungal diseases.

- Slaked lime applies at base of tomato plant, prevents damping off disease.

- Prepare 2 cup cattle urine $+5 \mathrm{ml}$ pepper mint oil in 10 litre water, uses for controlling fungal diseases.

\section{8) Termite control}

- The mixture of lime + sulphur is recommended into the soil for discouraging termite attack.

- In coffee bushes and date palms, Wood ash is applied around base of the trunk the prevent termite infestation.

- For termite holes, mix cattle urine with water in 1:6 and utilizes in termite control.

- For trunk coating, prepare cattle dung + red coloured clay with water and make into viscous fluid.

- Wipe on the trunk to control termites.

19) Control of leaf eating, sucking and fruit/shoot borers of vegetables

- Crush $1 \mathrm{~kg}$ green leaves of supli.

- Add in 10 litres water.

- Boil till solution reaches to half.

- Cool down the solutions.

- For 1 acre, prepares in 100 litres water.

20) Flyash-based herbal pesticides against pests of rice and vegetables

Flyash (FA) + turmeric 10\% dust and FA + 10\% neem seed kernel dust were found the most effective against large numbers of insect pests and Epilachna on brinjal and Spodoptera on okra.

$\mathrm{FA}+10 \%$ vitex dust, FA $+10 \%$ eucalyptus dust and FA $+10 \%$ ocimum dust were found the most effective against large numbers of insect pests and Epilachna on brinjal and Spodoptera on okra.

21) Crop growth promoter (KAMAAL 505) cum pesticide formulation

- Prepare two different solutions i.e., solution A and solution B.
- Solution A ingredients- neem (Azadhirachta indica) leaves + aak (Calotropis gigantia) leaves _ datura (Datura metal) leaves + bhang (Cannabis indica) leaves.

- Mix solution A by boiling.

- Solution B ingredients- tobacco powder + chiraita (Swertia chiraita) + Kutki (Picrorhiza kurroa) + bawachi (Psoralea corylifolia) + tamarind pulp + red chilli powder + reetha (Sapindus trifoliatus).

- mix solution B by boiling.

- Mix solution A + solution B with neem oil + tobacco powder + reetha (soapnut).

\section{2) Agrochem a herbal insecticide}

- Solution A- $50 \mathrm{gm}$ datura leaves + $50 \mathrm{gm}$ chandrajoyti (Jatropha grandulifera) $+50 \mathrm{gm}$ Ipomeae fistula leaves + $50 \mathrm{gm}$ tobacco $+50 \mathrm{gm}$ varul (Garuga pinnata) leaves +50 $\mathrm{gm}$ neem seeds $+50 \mathrm{gm}$ neem leaves $+100 \mathrm{gm}$ jowar tillers and $100 \mathrm{gm}$ congress grass.

- Prepare a paste of solution A.

- Solution B- Add 50 gm wavding (Embelia ribes) powder + $150 \mathrm{ml}$ kerosene +5 -teaspoonful soap powder (Nirma) in 3 litres water, boil the solutions, Add $200 \mathrm{ml}$ cow urine during boiling.

- Mix solution A and solution B in a container, store for 5 days.

- After 5 days, the solution is filtered and extracted.

- The extracted and filtered solutions are stirred well for 5 minutes to get final formulation.

- One part of formulation mixes with 100 parts water.

- Spray formulation in the insect control.

- Stores formulation for indefinite period of time and has no expiry period.

\section{3) Control of cotton pest}

\section{1-method}

- Crush and mix of leaves of Arni (Clerodendrum phlomidis) + kidimari (Aristolochia bracteata) + mamejavo (Enicostemma littorale) + neem (Azadirachta indica), make the juice.

- Filters and extracts the juice in muslin cloth.

- 200-500 ml extracted juice is diluted in 15 litre water for spraying in the crop.

- For 1 bhiga, dilute 30 litres extracted juice.

\section{2-method}

- Mix Kuvar or kuvar Pathu (Aloe vera) + karyatu (Canscora diffusa) + kokadva of Karen (Nerium indicum) + kadi jeeri (Nigella sativa) + custard apple (Annona squamosa) + kothimada (Cucumis callosus) + mamejavo (Enicostemma littorale) + inner bark of neem 'limdo' (Azadirachta indica) + marchi (Capsicum annum) + roots of 'saragvo' (Moringa oleifera) + washing powder in 20 litres water.

- Soak mix ingredients overnight.

- Filters $200-250 \mathrm{ml}$ and dissolve in 15 litres water.

- Spary 2-3 times depenmding upon insect attack.

\section{4) Tamarind and lemon for pest control}

- Mix $500 \mathrm{ml}$ tamarind juice with $500 \mathrm{ml}$ lemon juice in 15 litres water. 
- Sprinkles over the infested crop in 0.25 ha.

- Control of hairy caterpillar in castor crop.

\section{5) control hoppers in paddy}

- $1 \mathrm{~kg}$ Mukkadaka leaves + 10 liters water and boil.

- Filters the soilution.

- Dilute in 1: 10 ratio water

- Spray twice during nursery stage and transplanting stage.

- Effective against crabs.

\section{6) Control of leaf curl disease in brinjal}

- Collect spirogyra from the sea.

- Dry and preserve the spirogyra.

- Mix $2 \mathrm{~kg}$ dried spirogyra + $3 \mathrm{~kg}$ wood burnt ash+ 5 litre cow urine +40 litres water in the drum, kept 12 hrs.

- Filter the solution on muslin cloth, spray on the crop.

- Spray will be done 10 days interval.

27) Botanical growth promoter and pest control formulation

- Sothukathali (Aloe vera) leaves + neem leaves + tulsi (Ocimum tenuiflorum) leaves + nayuruvi.

- (Achyranthes aspera) leaves + Aristolochia bracteata leaves are prepared in boiled water.

- Spray in tomato and citrus crop.

\section{8) Termite management}

- Akada (Calotropis gigantia) $8-10 \mathrm{~kg}$ is soaked in water for 24 hours.

- Filter the solution, pour into termite infested soil.

\section{9) Caterpillar control in cotton}

- Add latex of Akda (Calotropis gigantia) in 15 parts water. - Spray on the crop, effectively controls the pest within 3 days.

\section{0) Management of nursery bed pests}

- Soak 0.5-1 kg Arithas (Sapindus emarginatus) in 1 litre water overnight.

- Crush softened nuts, filter the pulp through muslin cloth strain.

- Pour on the soil.

- Controls nursery bed pests such as white grubs, termites and others. (RCOF, 2019).

\section{CONCLUSION}

Adoption of modern agricultural technologies developed in various sectors of farming is useful for the progress of agriculture by improving production, productivity, food security and nutritional security. It will help to promote agribusiness and income generation from farming activities. It would also help to generate more employment opportunities benefiting the rural community. It will contribute to agro based industries, value addition, engineering industries, exports and improve the GDP of the nation.

\section{REFERENCES}

Archana, A.K. and Lekshmi, G.P.R. (2020). High pressure processing of fruits and vegetables: A review. Agricultural Reviews. 41: 347-355.

Cuaran, J. and Leon, J. (2021). Crop monitoring using unmanned aerial vehicles: A review. Agricultural Reviews. 42: 121-132.

Gol, (2019). National Action Plan for Egg and Poultry-2022 and Doubling Farmers' Income by 2022. Department of Animal Husbandry, Dairying and Fisheries, Ministry of Agriculture and Farmers Welfare, New Delhi, pp. 1-61.

Mahajan, S. Janailin, S. Papang, Singh, S. and Datta, K.K. (2015). Adaptation and mitigation strategies for dairy cattle: Myths and realities in Indian condition - A review. Agricultural Reviews. 36: 287-295.

Neila, B.S., Xavier, A. and Inma, E. (2016). Technology and Poultry Welfare. Animals. 6(62): 1-21.

RCOF, (2019). Organic agriculture and organic inputs. Chapter 1, Research centre of organic farming, Ghaziabad, pp. 1-76.

Rik, E., Ben, R., Pramod, A. and Marco, V. (2017). Family Dairy Tech India, Advisory Report, Van Hall Larenstein and Saxion Universities of Applied Sciences, Netherlands, pp. 1-92.

Suryatapa, D., Annalakshmi, C. and Tapan, K.P. (2020). Organic farming in India: A vision towards a healthy nation. Food Quality and Safety. 4: 69-76.

Varshini, S.V. and Jayanthi, C. (2020). Organic liquid manures and bio-fertilizers: A tool for soil and crop productivity. Agricultural Reviews. 41: 387-392.

Yadav, C. and Pandey, S. (2020). Status of the use of organic fertilizers in India: A review. Agricultural Reviews. 41: 338-346.

Zinich, L.V., Kuznetsova, N.A. and Kondratieva, O.V. (2021). Assessment of technical support for dairy industry in agricultural enterprises. International Conference on World Technological Trends in Agribusiness. 624: 1-6. 